\title{
47-Çă̆ romanı (Zeitroman) kavramına dair genel bir değerlendirme ${ }^{1}$
}

\section{Hatice GENÇ2}

APA: Genç, H. (2022). Çă̆ romanı (Zeitroman) kavramına dair genel bir değerlendirme. RumeliDE Dil ve Edebiyat Araştırmaları Dergisi, (26), 782-794. DOI: 10.2900o/rumelide.1074071.

\section{$\ddot{O} \mathbf{z}$}

Bu makale, çağ romanı türüne kavramsal ve kuramsal açıdan yaklaşarak anlamını ve gerçekliğin yer aldığı diğer roman türleriyle ortak ve ayrılan noktalarını ortaya koymayı amaçlamaktadır. Çünkü roman kavramının tanımına dair belirsizliklerin olması gibi içerik, biçim ve üslup gibi unsurların belirlediği roman türleri arasında da bir takım belirsizlikler yer almaktadır. Bir romanın birden fazla roman türü altında anılması bu duruma örnektir. Özellikle tarih ve edebiyat, geçmiş ve roman, kurmaca ve gerçeklik ilişkisi söz konusu olduğunda birbirlerinin sınırlarına dâhil olan roman türleri ortaya çıkmaktadır. Okuyuculara tarihin, dönemin ve toplumun panoramasını çizen oluşum romanı, tarihsel roman, gezi romanı, çă̆ romanı, toplumsal roman, aile romanı ve nehir romanı şeklinde farklı adlandırılmalara sahip romanlarda ortak nokta uzak/yakın geçmişte yaşanmış ya da o an cereyan eden olay ve olgulardır. Çalışmamızın konusu özellikle yakın tarihi konu edinen çă̆ romanı üzerine olduğu için bu roman türünün tanımı, felsefi alt yapısı, tarihsel gelişimi ve diğer roman türleriyle olan bağlantısı ele alınacaktır.

Anahtar kelimeler: Çağ romanı, tarihsel roman, tarihsellik, gerçeklik, kurmaca

\section{General evaluation on the concept of period novel}

\begin{abstract}
This article aims to reveal the exposition of the genre "Zeitroman" and its common and different points with other novel genres in which reality takes place, by approaching to this genre from a conceptual and theoretical point of view. Just as there are uncertainties about the definition of the concept of novel, there are also some uncertainties between the types of novels determined by elements such as content, form and style. Mentioning a novel under more than one genre of novel is an example of this situation. Especially when it's matter of the relationship between history and literature, past and novel, fiction and reality, novel types that are included in each other's borders emerge. The common point in the novels, which are called formation novels, historical novels, travel novels, age novels, social novels, family novels and river novels, which draw the panorama of history, period and society to the readers, are events and phenomena that happened in the distant / recent past or that take place at that moment. Since the subject of this article is especially on the "Zeitroman", which deals with recent history, the definition of this novel genre, its philosophical background, its historical development and its connection with other novel genres will be discussed.
\end{abstract}

Keywords: Period Novel, Historical Novel, Historicity, Reality, Fiction

Bu çalışma, Atatürk Üniversitesi Sosyal Bilimler Enstitüsü Alman Dili ve Edebiyatı Ana Bilim Dalı'nda hazırlanan "Bernhard Schlink'in 'Okuyucu' Adlı Eserinde Geçmişle Hesaplaşma” başlıklı yüksek lisans tezinden kısmen yararlanılarak hazırlanmıștır.

Dr. Öğr. Üyesi, Akdeniz Üniversitesi, Edebiyat Fakültesi, Alman Dili ve Edebiyatı (Antalya, Türkiye), haticegenc@akdeniz.edu.tr, ORCID ID: 0ooo-0003-1116-7351 [Araştırma makalesi, Makale kayıt tarihi: 12.01.2022kabul tarihi: 20.02.2022; DOI: 10.29000/rumelide.1074071]

Adres $\mid$ Address

RumeliDE Dil ve Edebiyat Araşttrmaları Dergisi Osmanağa Mahallesi, Mürver Çiçeği Sokak, No:14/8 Kadıköy - İSTANBUL / TÜRKIYE 34714 e-posta: editor@rumelide.com

RumeliDE Journal of Language and Literature Studies

Osmanağa Mahallesi, Mürver Çiçeği Sokak, No:14/8

Kadıköy - ISTANBUL / TURKEY 34714

tel: +90 $5057958124,+902167730616$

: editor@rumelide.com,

phone: +90 $5057958124,+902167730616$ 


\section{Giriş}

Roman kavramı köken olarak 12. yüzyılda Fransızca halk dilinde (Lingua Romana) yazılan manzum yapitlara verilen ad anlamına gelen "romanz" kavramına dayanmaktadır. Bu tarz yapitlar öncelikle bir kuraldan ziyade istisnai durumları temsil etmektedir. Bunun sebebi söz konusu bu dönemde yazılı edebi iletişime katılım, bilginlerin ve soyluların ayrıcalı̆̆ında olmasıydı. Bu nedenle Eski Fransız yerel dilindeki yazılan bu edebi yapıtlar, destanlardan farklı olarak kitap biçiminde dağıtılmalarına rağmen cehalet damgasını taşıyordu. 16. yüzyıla da kavramın adlandırılmasında kademeli olarak bir daralma söz konusu olmuştur. Böylelikle "roman" terimi 17. yüzyılda yabancı bir kelime olarak kabul gördügünde, günümüzdeki sadece akademik dilde değil, ilgili ulusal dilde düzyazı olarak yazılmış, uzun kurmaca bir anlatı anlamını kısmen karşılamaktaydı (Schneider, 2016: 8). Öte yandan roman kavramın belirli çevreler tarafından kabul görmüş kesin bir tanımı bulunmamakta ve hala katı bir çerçeveye oturtulmamıştır. Standart bir anlamı olmayan romanın, yüzyllar boyunca ifade ve şekil adlandırılması açısından sürekli değişikliklere maruz kalmıştır. Dolayısıyla "roman, gelişmekte olan, evrimini tamamlamamış tek türdür" (Antakyalığlu, 2013: 21). Bu nedenle roman aslında belli bir kanona uymamaktadır. Ancak geniş kapsamlı uzun bir edebi tür olması ve diğer türlere oranla tarihle en yakın bağa sahip olması nedeniyle çağın sorunlarını kurmaca boyutuna taşıyabilmektedir (Ecevit, 2000: 92). Arka planında kurmaca ya da gerçekliğin yer aldığı bu türün merkezinde insan yer almaktadır. Onun iç dünyası, deneyimleri ve onun belli bir zaman içerisinde kendisiyle veya çevresiyle olan ilişkileri bulunur.

Romanlar, yazıldığı tarihsel dönemlerine, konularına, içeriklerine, yapısal özelliklerine ve hedeflediği okuyucu kitlesine göre çeşitli sınıflandırmalar altında anılmaktadır. İçerdiği konu ve konu malzemesi bakımından tarihten ya da yakın geçmişten beslenen, daha doğrusu malzemesi gerçek gerçeklik olan romanların adlandırılması konusunda dikkat edilmesi gereken birtakım ölçütler bulunmaktadır. Malzemesi geçmiş olan tarihsel roman tarihselliği, bugünü geçmişten türetip geleceğe doğru götüren bir süreç olarak şart koşmaktadır. Bu açıdan bakıldığında tarihi konu edinen romanların güncel olma gibi bir özelliği yer almaktadır. Güncel olması gereken çă̆ romanı bir dönemin toplumlarının ve kişilerinin gösterilmesiyle adı geçen dönemin kendisini ve çă̆ını eksiksiz ve makul bir şekilde tasvir eden bir roman çeşidi olup çoğunlukla toplumun gerçeğe bağlı yansımalarını ve söz konusu dönemle ilgili yapılan analizleri ve en önemlisi çağın genel görünümünü analiz etmektedir. Psikolojik ve kültürel unsurların ağır bastığı çă̆ romanında yazarın bahsettiği dünya olaylarının insanlar üzerindeki etkileri gerçekçi bir şekilde ele alınmaktadır. Bu nedenle çă̆ romanları birer çağ eleştirisi olarak da adlandırılmaktadır.

Yapıtında çă̆ın genel görünümünü vermeyi amaçlayan yazarın tarihi bilgilerle donanmış olması ve yapıtını ele almadan evvel bir müddet araştırma yapması gerekmektedir. İtalyan yazar ve akademisyen Umberto Eco bu duruma örnektir. Eco, "Gülün Adı" adlı romanını yazmadan önce Kutsal Kitaplar, Doğu ve Batıya ait klasik eserler ve tarihi belgelerden yararlanarak derin bir tarihi araştırma gerçekleştirmiştir. Örneğin 14. yüzyıl İtalyası’nda hüküm süren toplumsal ve dinsel karışıklığı okuyucuya hissettirebilmek adına eski tarihi kayıtlarda yer alan suçluların isimlerini listelemiştir (Eco, 2011: 114). Eco’ya göre "kurmaca metinler mekan olarak bizim yaşadığımız dünyadan tamamıyla farklı bir dünyayı" (Eco, 2011: 69) kullanmadıkları için bilimsel gerçeklerden hareket etme söz konusudur. Eco, "Gülün Adı" yapıtına kaynaklık eden gerçek bir el yazmasından hareket ettiğini ancak kurmacanın da yer alması gerektiğini şu şekilde vurgulamıştır.

"Manastırm hem krokisini hem de yerini uydurduğumu söylememe gerek yok (ama ayrntılarm pek çoğunda gerçek mekanlardan esinlenmiştir); eski bir el yazması bulunduğunu söyleyerek bir kurmaca kitaba başlamanın saygıdeğer bir edebi topos olduğunu, hatta sunuş yazıma "Doğal Olarak, Bir Elyazması" başhğını koyduğumu; hem Kircher’in gizemli kitabını, hem de ondan daha

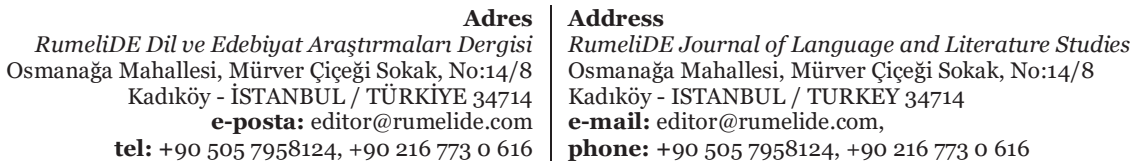


gizemli olan sahafi da benim uydurduğumu söylememe de. Gerçek manastırı ve gerçek elyazmasını arayanlar belki de edebiyatın usullerine yabancı olan saf okurlardı [...] kültürel konumları ne olursa olsun pek çok okur, kurmacayla gerçek arasındaki farkı göremiyor ya da göremez hale geliyor. Kurmaca karakterleri, sanki onlar gerçek insanlarmış gibi ciddiye aliyor.”(Eco, 2011: 62)

$\mathrm{Bu}$ şekilde Eco, okuyucuyu, okuduklarının gerçeklik boyutunu araştırma konusunda görevlendirmektedir. Okuyucu bu şekilde anlamlandırmada aktif bir konuma gelmektedir. Ancak öte yandan romanın önemli unsurlarından olan kurmaca, bir anlatı türüyle ilgilenen roman yazarı için en önemli aracıdır. Öte yandan bir tarihçi sadece elindeki veriler doğrultusunda söz sahibi olmak zorundadır. $\mathrm{Bu}$ yüzden romancının kurduğu hayali tarihçi kuramaz ve tarihçi asla romancının esnekliğine sahip olamaz. Çünkü tarihçi tarihi olduğu gibi aktarmaya mecburdur. Aristoteles, "Poetika" adlı yapıtında tarih yazımı ve kurmaca arasındaki ayrımı şu şekilde netleştirmiştir:

"Tarihçi daha çok gerçekten olan'ı, ozansa olabilir olan'ı anlatır. Bunun için şür, tarih yapıtına oranla daha felsefi olduğu gibi, daha üstün olarak da değerlendirilebilir. Çünkü şür, daha çok genel olanı, tarihse tek olanı anlatır. [...] Ozanlar ilkin olasılı yahut zorunluluk yasalarına göre öyküyü oluştururlar. Sonra, bu öyküye uygun olarak da yapıtta geçen kişileri adlandırırlar" (Aristoteles, 1987: 30).

Bu bağlamda roman yazarına düşen ise sadece gerçeğe benzetmektir ve gerçekleşme ihtimali üzerinde durular. Gerçek dünyaya ait kişi ve mekân isimleri kullanmalarına rağmen temelde kurmacanın etrafında gezinirler. Göğebakan ise tarihçi ve romancı arasındaki farklılığa somut bir örnek vererek yaklaşmıştır.

\begin{abstract}
"Romancının yalnızca bir işi vardır. O, anlattığı şeyleri tutarl, anlamlı bir resim haline getirmek zorundadır. Ancak doğruluk gibi bir endişesi yoktur. Buna karşıllk tarihçi, hem tutarl ve anlaml bir resim oluşturmak hem de bu resim içerisinde anlatılan olaylarm gerçekte olduğu gibi yansitılmasına dikkat etmek zorundadır." (Göğebakan: 2004: 36)
\end{abstract}

Tarihçi, tarihi roman yazarının kurgulama ve yaratma sürecindeki özgürlüğüne sahip değildir. Bir roman yazarı tarihi olaylara yaklaşırken esnek davranmakta, gerçeklemiş tarihi olayları olduğu gibi aktarmak yerine istediği olayı görüp istemediğini göz ardı ederek, dilediği gibi şekil verebilmekte ve bu sayede dünyayı algılayış biçimini ortaya sermektedir. Hatta tarihçinin anlatmak zorunda kaldığı gerçek karakterlerin yanında kurmaca karakterler de yaratarak tarihi karakterlerin daha iyi tanınmasına vesile olmaktadir.

Tarihçi ile tarihsel roman yazarının arasındaki bir diğer fark ise geleceğe olan bakış açılarında yer almaktadır. Tarihçi geçmişteki bir olayı objektif bir biçimde aktarırken bugünün şartlarını göz ardı eder, oysa romancı için gelecek müjdecisi görevi ile insanı sarsmakta ve avutmaktadır. Tarihsel romanlar bize tarihi ders kitapların aktaramadığı bazı noktaları gerek doğrudan gerekse kurmaca yoluyla aktarmaktadır ve böylelikle tarih gerçek ve kurmacanın bir arada olduğu bir koordinatta somut bir konum elde etmektedir. Bu nedenle Aust tarihsel romanın kökeninin tarihi geçmişin anlatıcının dile getirdiği özel bir kataloğundan gelmediğini, aksine anlatıcının geçmişteki bu boşlukları somutlaştırmasından başka bir ifade ile güdüleme, araç seçimi, sonuç, etki ve değerlendirmesi hakkındaki anlatısal bilgilerle doldurmasından ileri geldiğini vurgulamaktadır (Aust, 1994: 31).

Kökeni Almanya'ya ait olan ve 18.yüzyllın ikinci yarısına dayanan çağ romanın filizlenmesine vesile olan tarihsel romanını da yakından etkileyen olay Fransız Devrimi olmuştur. Çünkü 1780’lerin başında edebi aydınlanmanın etkisiyle romanın "tarihin kardeşi" olarak algılanması tarih anlayışının zamanlaştırılmasına ve çağ romanın gelişmesine neden olmuştur (Göttsche, 2007: 882). Bu tarz roman yazarları kendilerini sosyal ve politik angaje doğrultusunda güdümlü edebiyat (Tendenzliteratür)

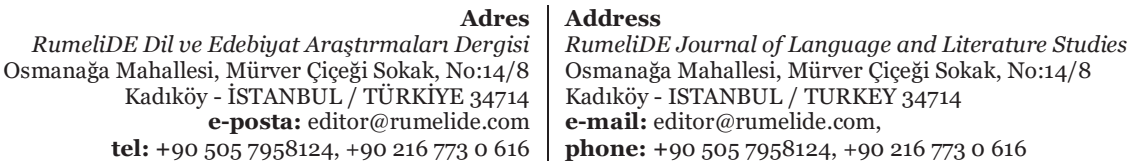


denilen siyasi amaçla yazılan edebi türlerin öncüleri olarak görmektedir. Güdümlü edebiyatın bir parçası olması çă̆ romanın belirleyici özelliklerinden birisidir. Çă̆ romanın söz konusu bu öncülerinden sayılan Friedrich Spielhagen "Beitrage zur Theorie und Technik des Romans" (1883) adlı yapıtında, çă romanı yazarının baskıyı ve gücü içinde hisseden coşkulu insanın kaderine engel olmaya çalışmasını fark etmiştir. Spielhagen'e göre 1837'de Theodor Mundt'un çă̆ romanı hakkındaki "her boyutta insan yönlerinin toplam imajına" (Meid, 1999: 563) dair olan görüşü de realizm döneminde de devam etmiş ve "epik nesnellik" talepleriyle birleştirilmiştir.

Çağ romanlarında esas olan nokta, yapitların siyasi yönünün ağır basması ve burada bahsedilen dönemin siyasi ve sosyal izlerinin günümüzde de görülebilir olması veya etkilerinin devam etmesidir. Okuyucular bu tür yapıtlarda sadece ele alınan edebiyatının büyüleyici/etkileyici olan çağını öğrenmekle kalmaz, aynı zamanda o dönemdeki devletin/toplumun sansür ve basın özgürlüğü için gürültülü mücadelesinin geçmişi hakkında bilgi de edinmektedir. Bu bağlamda genç Almanya yazarları, Karl Gutzkow'un "Die Ritter vom Geiste" örneğinde olduğu gibi içinde bulundukları dönemin mümkün olduğu kadar kapsamlı ve eksiksiz bir panoramasını vermek için çă̆ romanından faydalandılar (Wolfgang, 2006: 49). Gutzkow ise söz konusu bu yapitında ilk kez "Nacheinander" yerine "Roman des Nebeneinander" uygulamıștır. Bu kavram şu anlama gelmektedir: Bu roman, derli toplu bir arada bulunan çok sayıda figür ile geleneksel merkez perspektifli anlatımın çiğnemiş ve birbiriyle bağlantılı çok sayıda farklı olay örgülerine dağılmıştır. Ayrıca "suç ortamından yönetici aileye kadar toplumun tüm alanlarını" (Meid, 1999: 563) kapsaması ve karakterize etmesi bakımından çağ romanının dönemin birer kültür tablosu olduğunu da ispatlamaktadır. Bu bağlamda Theodor Fontane bir mektubunda çağ romanı hakkında "çoğulluk romanı" (Meid, 1999: 564) olasılı̆̆ından bahseder.

\section{1. “Çă̆ Romanı” tanımı}

Almanca karşılığı "Zeitroman" olan çağ romanı tarihi konu edinen romanların bir alt başlığıdır ve genel itibariyle 18. Yüzyılın ikinci yarısında gelişmeye başlayan çağ romanı çağın panoramasını merkezinde tutan bir roman tipidir. Bu roman tipi "çağın koşullarında, ana hatlarında ve gelişmelerindeki (belgelere dayah ya da kurmaca) panoramasinn edebi çabası olarak politik ve/ve ya toplumsal günümüz tarihinin betimlenmesi ve eleştirilmesiyle" (Göttsche, 2007: 881) oluşmaktadır. Bir başka ifade ile çă̆ romanı çağdaş bir metni anlaşılır kılmak için günümüz şartlarının bir portresini çizmektedir.

Hugo Aust "Der Historische Roman" adlı yapitında tarihi konu edinen romanların alt tipleri için gerekli olan ölçütün şu anki zamana olan mesafesine göre değişkenlik gösterebileceğini dile getirmiştir. Buna örnek olarak Walter Scott'ın "Waverley" adlı yapıtının çok daha eski, "Ivanhoe" adlı yapıtının ise daha yakın geçmişe ait olduğunu söylemiştir. "Waverley”i kinayeli bir biçimde "bugünün bir parçası olarak tarih öncesi" şeklinde yorumlarken "Ivanhoe”yu da mecazi anlamda "bugüne oranla ilk çağ” olarak nitelendirmiştir (Aust, 1994: 32). Argunşah bu bağlamda tarihsel roman yazarının "yaşadiğı devrin uzağındaki bir zamanda gerçekleşmiş olaylar konu alarak onlar yeni baştan hatta kendi yaşadığ devrin meseleleriyle de ilgiler kurarak" (2016:10) işlediğini bu yüzden de tarih nesilden nesle aktarllan bir milli kültür unsuru haline geldiğini vurgulamıştır. Bu bağlamda tarihsel romanın şimdiki zamanla ilişkisinin bulunduğu görülmekte ve ortaya yeni bir bakış açısı çıkmaktadır. Aust bu zaman mesafesinin şimdiki zamana daha yakınlaştırılması, tarihsel romanın bilinçsizce çağ romanı denilen türe doğru yöneldiğini ifade etmiştir (Aust, 1994: 32). Bu durumda çağ romanın en karakteristik özelliğinin saptanmasında kullanılan yöntem yazarın yapıtında dile getirdiği döneme olan uzaklığı ve tutumunun belirlenmesidir. Göğebakan’a göre (2004: 16) bir romanın tarihsel roman olarak adlandırılmasında

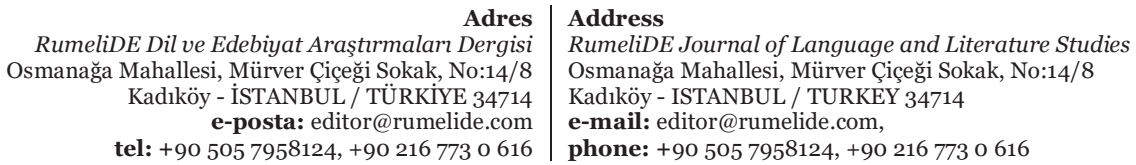


Scott geleneğine bağlı kalınarak olayın gerçekleştiği tarih ile yazarın bunu yapıtına aktardığı tarih arasında oluşan zaman mesafesinin yaklaşık 70 yıla tekabül eden iki-üç kuşaklık bir zaman aralığının bulunması gerekmektedir. Bu bağlamda "bugünle arasında sağhkkl bir değerlendirme yapmaya olanak verecek bir zaman mesafesi” (Göğebakan, 2007: 502) tarihsel romanın kriterlerinden birisidir. Yazar, bu durumda yapıtında dile getirdiği olayı ya bizzat şahit olmuştur ya da şahit olan birisinden okuyucuya aktarmaktadır. Scott geleneğine bağlı kalınması durumda tarihsel romandan kastedilenin, tamamen geçmişte yaşanıp sona ermesi gerektiği anlaşılmaktadır. Ancak yazar yaşadığı bir dönemin insanlık tarihi için gelecek kuşaklara aktarılacak olan bir olayı bizzat görüp hissederek yapıtına aktarması söz konusu olduğunda da bu romanı niteleyecek bir kavramın olması gerekmektedir. Bu bağlamda Göğebakan’ı “çağ romanı” kavramının, zaman sorunu tarafından belirlendiğine dair görüşleri aşağıda yer almıştır.

"Olayın gerçekleștiği tarihle yazarm onu bir yazınsal malzeme haline getirdiği tarih arasındaki zaman arah̆̆ı sorunu, yazınbilimcileri çok uğraştıran konulardan biridir. Şundan; yazarm ele alacağı tarihsel olaya karşı takınacağı tutumu belirleyen öğelerin başında geliyor bu.”(Göğebakan, 2004: 15-16)

Çă̆ romanı bu bağlamda farklı bir açıdan da ele alınmaktadır. Örneğin Thomas Mann “Büyülü Dağ” adlı romanını kendine has farklı iki anlamda çağ romanı olarak tanımlamıştır. Bu çift anlamlılığın ilk açıklaması oldukça açıktır: sınırlı olan Davos adlı olay yerindeki olay belirli tarihsel bir devirdeki daha büyük olan insanlık olayını sembolize etmektedir. Asıl arka planda yatan ise ikinci nüanstır. Bu roman bir çağ romanıdır, çünkü burada zaman sadece anlatının bir ögesini değil, aynı zamanda anlatının konusunu tasvir etmekte, yazar bu yapitında zamanı anlatmak istemektedir (Hillebrand, 1978: 96). Dolayısıyla çağ romanlarında zaman kavramı hikâyenin unsuru ve aynı zamanda hikâyenin konusudur. Bu açıdan bakıldığında Thomas Mann'ın bu yapıtında zamanın asıl madde olması nedeniyle zaman romanıdır. Ayrıca Avrupa'nın farklı yerlerinden gelen sanatoryumda savaş öncesi Avrupa'yı ve düşüncesini okuyucuya aktardığı için çağ romanıdır (Tepebaşılı, 2005: 78). Zaman kavramı "Büyülü Dağ” için hem içeriksel boyuttur hem de biçimsel.

Gürsel Aytaç'a göre "çă̆ romanı" yapıtta ele alınan ve bahsi geçen toplumun ve dönemin görünümü hâlinde yansitan bir roman çeşidi olup "XIX. yüzyılda gerçekliğe gösterilen rağbete bağh olarak ortaya çlkan bu roman çeşidi, objektif bir dönem görünümü vermeyi amaç edinirken düşünsel bir analizi de beraberinde getirir" (2003: 332). Ayrıca Aytaç Zeitroman kavramının Türkçe karşıllı̆ı olarak "zaman romanı" da demekte ve şu şekilde gerekçelendirmektedir:

\begin{abstract}
"Zaman romanı zamanı konu alarak işleyen romandır. Bu tanımda zaman genis dar iki anlamda kullanılmıştır. Demek oluyor ki bu tür romanlar ya belli bir zamanı ya da zaman konusunda değişik bir görüş getirmeyi, zaman kavramına yeni bir yaklaşımı, uygun imajlar ve uygun anlatım tekniğ $i$ içinde dile getirir. Bu anlamda eser, bir çeşit deneyci roman (experimentierender Roman) olma yolundadır.” (Aytaç, 1999: 219).
\end{abstract}

Argunşah tarihi konu edinen bir yapıtta dile getirilen zamanın yazarın yaşadığı döneme uzak bir dönemi aktarması durumunda tarihsel romanın varlığından söz etmekte ve bu ilişkiyi Kemal Tahir'in "Devlet Ana” ile Halide Edip Adıvar'ın "Ateşten Gömlek" yapıtları üzerinde karşllaştırma yaparak somutlaştırmaktadır. Bu iki yapıtın kaynağı tarihi gerçeklerdir; ancak yazarların yapıtlarında dile getirdikleri olaylara zamansal yakınlığı bakımından farklı iki tür söz konusudur. Kemal Tahir "Devlet Ana”da tarihsel belgelerden yola çıkarak olayları anlatırken, Halide Edip Adıvar “Ateşten Gömlek”te yer alan dönem ve gerçeklikler yazar tarafından bizzat yazıldığı dönem ile uyuşmaktadır. Bu durumda "Devlet Ana" tarihsel romanken diğeri çağ romanıdır. Birinde öğrenme söz konusuyken diğerinde yazarın yapıtta bahsedilen dönem içindeki tecrübesi esastır (Argunşah, 2002: 458). Demek ki yeniden

Adres $\mid$ Address

RumeliDE Dil ve Edebiyat Arașttrmaları Dergisi $\quad$ RumeliDE Journal of Language and Literature Studies

Osmanağa Mahallesi, Mürver Çiçeği Sokak, No:14/8 $\quad$ Osmanağa Mahallesi, Mürver Çiçeği Sokak, No:14/8 Kadıköy - İSTANBUL / TÜRKIYE 34714 Kadıköy - ISTANBUL / TURKEY 34714 e-posta: editor@rumelide.com e-mail: editor@rumelide.com, tel: +90 5057958124, +902167730616 phone: +90 505 7958124, +90 2167730616 
Scott geleneği göz önünde bulundurulduğunda romanın tarihsel roman olma özelliği için en az iki ya da üç kuşak gerektirmesi de zaten yazarın yapıtında işlediği olayın yaşama ihtimalinin olmadığını ispatlamaktadır. Çă̆ romanı yazarından bizzat olayları yaşaması ya da en azından kendisinden önce gerçekleşen buhranlı olayların izlerini yaşaması beklenmektedir. Göğebakan'ın ifade ettiği gibi çă̆ romanı yazarı "içinde yaşadığı zamana ayna tutarak, ona egemen önemli olayları ve bu olayların arkasındaki tarihsel-sosyal gerçekliği” (Göğebakan, 2007: 503) bir bütün olarak ele almaktadır. Bu nedenle bu kuşak ölçütünün dışında kalan tarihi çă̆ın panoramasını, toplumsal ve kültürel değişiklikleri bu şekilde veren yapıt, çă̆ romanı olma özelliğine sahiptir. Aynı şekilde Tural da yaşanılan olay ile bu olayın yazıya aktarılmasındaki zaman mesafesine dikkat çekerek tarih konulu romanın çă̆ romanından farkını şu şekilde dile getirmiştir:

"Çağını konu edinen eserlerden farkı, işlenilen vak'anın, halde devam etmesi yerine başlangıç ve sonucu, gözlenebilen zamandan önceye dayanmasıdır.[...] konusunu yazarm şahidi olmadığı bir geçmişten alan her deneme, edebi ölçülerle, tarihi roman sayılmaz.” (Tural, 2003: 211)

Bu durumda devreye yine çağ romanı girmektedir. Çünkü tarihsel roman için "gerekli şart, konunun tamamlanış, bitmiş, zaman mührünü yemiş olması” (Tural, 2003: 212) gerekmektedir. Çağ romanı için ise yazarın içinde bulunduğu dönemin/toplumun düşünce ve deneyim tarzını anlatım sanatının gereklerine uygun bir biçimde şekil vererek politik-sosyal ve zihinsel kültürel panoramasını çizen yapıt anlaşılmaktadır (Rinsum, 2006: 48). Bir sona kavuşmamış veya etkisinin hala hissedildiği bir çağı konu edinen bir yazar, çağdaş toplumu analiz eder ve genellikle toplumsal açıdan eleştirel niyetlerle kahramanlar üzerindeki etkisini sunar. Bir yandan okuyucu, eylemin gerçekleştiği zamanın ruhuna dair bir içgörü kazanırken, diğer yandan toplumsal ya da toplumsal olayları anlayabilir. İçinde bulunduğu siyasi koşulları daha iyi ve daha eleştirel bir şekilde anlayan çă̆ romanı yazarı, okuyucuya ele aldığı zaman hakkında kapsamlı bilgiler aktarmayı amaçlamakta ve toplumun ve bireyin yaşamak zorunda oldukları zahmetli hayat şartlarını olan incelemektedir. Bu nedenle bu tarz yapitlarda çok sık çă̆ eleştirisi yapılmaktadır. Örneğin çağ eleştirisi yaparak, insanın içinde bulunduğu özellikle olumsuz şartları dile getirerek farkındalık yaratmaktadır. Çă̆ romanında Weimar Cumhuriyeti demokratik ve sosyal güçlerinin başarısızlı̆̆ , Nasyonal Sosyalizmin iktidarı ele geçirmesi ve yasaya aykırı davranma gibi politik öğelerin de önemli bir yeri vardır. Buradaki amaç yine aynı şekilde çağ romanının günümüze ait olan politik kültürün tablosunu çağdaş konteksti anlaşılır ve kanttlanabilir kılmaktır. Bunun için de siyaseti bir amaç için kullanmaktadır (Glaser, 1983: 123-124). Siyaseti bir amaç için kullanan yazarlara örnek olarak çağ romanlarıyla ünlenen Günter Grass gösterilmektedir. Yazarın siyaseti bir amaç için kullandığı yapıtlarında şu iki nokta ön plana çıkmaktadır:

"Yazar, Nasyonal Sosyalizmin gelişiminden küçük burjuvazinin özellikle suçlu ve sorumlu olduğu düşüncesini sürekli olarak gündeme getiriyor. Neredeyse bütün çağ romanlar, okuyucunun bu suçluluk ve sorumluluk duygusunu kolayca algılamalarını sağlayan öğelerle doludur” (Göğebakan, 2004: 206).

Grass, yapitlarında bizzat tanık olduğu, yaşadığı ve hala içerisinde bulunduğu dönemi anlatmaktadır ve yapıtın gerçeklik boyutunu yansıtan ve aynı zamanda konusunu oluşturan bu dönem, yazarın parçası olduğu toplum ve toplumun geleceği için dönüm noktası bir özelliğe sahiptir. Bu bağlamdan hareketle Grass gibi çă̆ romanı yazarları, toplumun aksaklıkları, adaletsizlik ve sosyal çelişkiler hakkındaki fikirlerini açıkça söyleyip savunan kişilerdir. Çağı eleştirisi yapan bu yazarlar bu bakımdan gerçeklik algısına diğer türlerdeki roman yazarlarından daha fazla bağlıdır (Hartmann, 739). Çă̆ romanı güncel ve herkesin dilinde olan konuları benimsemekte ve savaş, savaşın neden ve sonuçları, enflasyon, işsizlik, gibi kültürel ve ekonomik olayları yansıtmaktadır. Bu nedenle bu yazarlarının amacı mümkün olduğunca geniş bir okuyucu kitlesini yapıtlarında yansıttıkları bu tarz durumlarla yüzleştirmektir.

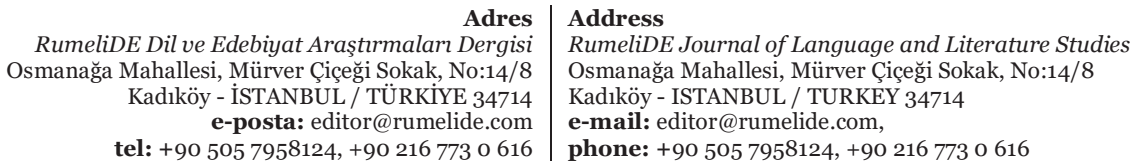


Kurgu özelliğinden olayı bu aktüalitenin yanında kişisel deneyim, düşünme ve konuşma biçiminin bir belgesi olarak okuyucunun karşına çıkmaktadır.

Çağ romanın bir diğer önemli özelliği tarihi olayları bir bütün olarak ele almasıdır. Tarihsel romanda yazar yapıtında özellikle sadece bir olay üzerinde yoğunlaşırken, çağ romanında "olaylar ya da tarihsel bir durum söz konusudur” (Göğebakan, 2007: 503). Kronolojik bir şekilde ilerleyen bir olay örgüsünün peş peşe sunulmasının yerine, artık çok sayıda eş zamanlı olarak gerçekleşen farklı anlatı demetinin bir arada bulunması söz konusudur. Bu bir arada bulunan olay örgüleri birbirlerine karşıtsal olarak da çağın genel görünümünü verebilmektedir. Bu sayede çă̆ romanları okuyucuları ise yansitılan dönem hakkında yapıtın kahramanından daha çok bilgiye sahip olmakta daha çok bilinçlenmektedir.

Tarihi bir bütün olarak ele alan çağ romanı dönemin genel bir bakışı sunma amacında beraberinde getirmektedir. Farklı tasvir edilen alanlar çok sayıda anlatı yumağında bir arada bulunmaktadır. Yapıtta dile getirilen dönemi tüm boyutlarıyla okuyucuya sunmak için yazar, figür sayısında ve çeşitliliğinde cömert davranmaktadır. Çünkü çağ romanının konusu etkili olan güçlerin ve eğilimlerin eş zamanlı bütünlüğü olarak çok sayıda ve farklı sınıflardan kahraman aracılı̆̆ıyla üretilmektedir. Yapıttaki kahramanlar aynı zamanda etkili çă̆ akımlarının taşıyıcısıdırlar, bu bakımından özellikle Bildungsroman'daki merkezi öznellik sosyo-kültürel rol yönlendirilmelerine indirgenmektedir (Stöckmann, 2011: 148). Bu nedenle çağ romanlarının başkişisi ortalama bir insan tipinden ziyade sıradan niteliklere sahip birisi olmasının yanı sıra bu romanlardaki kişilerin karakteristik özelliklerinden ziyade, onların hayatlarını etkileyen istisnai tarihi olayların aktarılması ön plandadır. Bu durum Realizm'deki çağ romanı için geleneksellikten uzaklaşarak, yeni bir görüş ortaya atılmaya neden olacaktır. Bu yüzden Gottfried Keller’in "Der grüne Heinrich" (1854/55) adlı en önemli gerçekçi sanatçı romanı, ressam Heinrich Lee'nin sadece yükselmesi değil aynı zamanda çabalarının boşa çımasını dile getirmesi çă̆ romanlarının ayırt edici özelliğidir (Rinsum, 2006: 49).

Çă̆ romanındaki figürlerin fonksiyonu öncelikle yazarın çok sayıda bağımsız biçimler yardımıyla dünyayı ve zaman evreninin şifresini çözmeye ve tasvir etmeye çalışmasıyla belirlenmektedir. İnsanlar dış dünyanın temsilcileri olarak bu amacı gerçekleştirmek için sadece birer araçtır. Buna aracılık ettikleri için ise medial olarak adlandırılmaktadır. Çağ romandaki çoğu figür, yazarın sanatsal ve kompozisyonsal hedefleri nedeniyle bugünkü zamanın tarihsel önemi gerçeğinden daha az güvenirlilik elde etmektedir (Jeske, 1981: 448). Burada önemli olan tarihsel gerçekliğin sadece tek bir ana karakter aracılığı ile değil, çok sayıda eş değer temsilciler aracılığıyla vurgulanmasıdır.

Çağ romanındaki diyalog, figürlerin toplumdaki konumlarını, kendilerini ifade etmelerini ve her durum için partizanca kendilerine bir yer belirlemek şartıyla bağlantılarını veya zorunluluklarını gösterebilmelerini mümkün kllmaktadır (Jeske, 1981: 445). Bu nedenle diyaloglarda ve dramatik anlatımdaki katkısı sayesinde episodiğe yönelme artırılmaktadır. Çağın sorunları esas olarak münazaralarda ve sözlü tartışmalarda sunulmaktadır (Stöckmann, 2011: 148).

\section{2. Çağ Romanının tarih kaynaklı romanlarla ilişkisi}

Roman türü araştırmaları dahilinde yapılan çalışmalar spesifik ve kesin sınırları belli olan bir adlandırmanın olmadığını göstermektedir. Bu bağlamda çağ romanlarını tarihsel roman olarak gören yanlış bir anlayış hüküm sürmektedir. Oysa her iki tür arasında kurgu benzerliği olmasına rağmen çok önemli farklar yer almaktadır. Örneğin tarihsel roman kendi çağını yansıtan çă̆ romanından farklı olmasında ve tarihsel roman ve çă̆ romanın sınıflandırılmasında esas noktalardan biri günümüzle ilgili

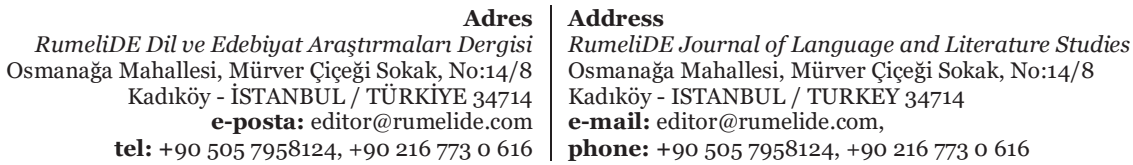


olup olmamasıdır. İçerdiği konu şimdiki zamana yaklaştıkça, çağ romanı ile benzerlik göstermektedir. Çă̆ romanın kökleri sadece anlattı̆̆ı çağ ile sınırlı değil, bugüne kadar uzanmaktadır.

Hugo Aust’a göre bir romanı tarihsel roman olma özelliğini sağlayan karakteristik özellikler bulunmaktadır. Öncelikle tarihsel roman içerisinde geçmişe işaret eden tarih, kişi, yer ve dönem ismi, kültür tarihine ilişkin detaylar ve resmi belgeler gibi bir takım ögeleri içerisinde bulundurmalıdır. Geçmişe değil de kurmacanın yerine geçseler bile bunların hepsi zamana bağlı farklılı̆̆ı ve mesafeyi ifade etmektedir. Okuyucunun durumu, yapitın oluşumu ve anlatılan zamandan oluşan ilişki üçgeninde etkisini göstermektedir (Aust, 1994: 22). Çünkü bu kavramlar okuyucuya yapitta bahsedilen olayların gerçekleştiği dönemi hakkında ipuçları vermektedir.

Argunşah tarih romanı yazarının "yaşadığı devrin dışında bir zamanda gerçekleşmiş olayları konu alarak onları yeni baştan hatta kendi yaşadığı devrin meseleleriyle de ilgiler kurarak" (2006: 421) işlediğini bu yüzden de tarih nesilden nesle aktarılan bir milli kültür unsuru haline geldiğini vurgulamıştır. Bunun yanında Argunşah tarihi roman hakkında genel ölçütleri çerçevesinde kesin olarak şu tanımı yapmıştır:

"Tarihi roman, başlangıç ve sonucu geçmiş zaman içerisinde gerçekleşmiş olan hadiselerin, devirlerin ve bu devirlerde yaşamış olan insanların hikâyelerinin edebi ölçüler içerisinde yeniden inşa edilmesidir.” (Argunşah, 2006: 428)

Bu bağlamda tarihsel roman yazarı, yapıtında dile getirdiği çă̆ ya da zaman aralığını bizzat yaşaması ya da tanık olması gerekmektedir. Tural'a göre tarihsel romanı diğer romanlardan ayıran birinci ve en önemli özelliğin yazara göre daha uzak geçmişteki gerçeklere dayandırılmasıdır. Çağı konu olarak ele alan diğer romanlardan farkı, işlenen durumun şimdiki zamanda da sürmüyor olması ve başı ve sonu gözlenebilen zamandan önceye dayanmasıdır (Tural, 2003: 208-209). Yazarın içinde bulunduğu dönemi aktarması, romanın kurgusunda yer alan kurmaca bağlamında önemli bir etkisi söz konusudur. $\mathrm{Bu}$ durumun yazarın daha nesnel bir tutum sergilemesine neden olmaktadır.

Çă̆ romanında yazarın bizzat yaşadığı dönemi sıcağı sıcağına aktarması söz konusudur ve yazar hala yaşanılan olayların etkisi altındayken romanlaştırma sürecinde objektif olma konusunda zorluk yaşayabilmektedir. Empresyonist bir çizgide yer alan bu tür romanlarda gözlem ve üsluba yeterince yer verilmediği için gelecek kuşaklara aktarılırken bir takım yanlışlardan kaçınılamaz hale gelebilmektedir. Tarihsel romanlarda günümüz hakkında yansız düşünmek için yaşanan olay ile bugün arasındaki bu zaman mesafesi vurgulanmaktır. Bu nedenle çă̆ romanında yazarın tarafsızlığı sorgulanabilmektedir.

Scott’ın 2-3 kuşaklık ölçütünün arka planında çağ romanın “geçmiş olarak bugünü” (Glaser, 1983: 136) aktarması yer almaktadır. Peter Hasubek'in düşüncesine göre çağ romanın en karakteristik özelliği "roman konusunun güncelliği" ve "yazarm güncellik çabası" (a.g.e., 1983: 136) olup kurgusal tarihi bugünün anlayışının aracı haline getirmesidir. Ancak güncellik kavramı kurgusal zaman ile okuyucunun içinde bulunduğu tarih arasındaki sınırı aşmaması gereken kronolojik çıkarım yöntemi olarak anlaşılmaktadır (a.g.e., 1983: 136). Bu bağlamda çă̆ romanı, işlediği olay ve figür açısından yazıldığı dönemde daha yakın geçmişe ait olmaları nedeniyle güncel romanlardır. Ancak tarihsel romanda anlatılanlar ile okuyucunun içinde bulunduğu dönem ile arasında yaklaşık 2-3 kuşaklık zaman aralığının bulunması gerekmektedir. Yakın çağ romanında (özellikle iki dünya savaşı arasında) ve 1950 ve 1960 ’lı yıllardaki "geçmişle yüzleşme romanı"nda tarih öylesine yakındır ki aradaki zaman mesafesi kriterine bağlı olarak tarihsel romana konu olma özelliğinden uzaklaşmaktadır (Aust, 1994: 32). Şimşek de çă̆ romanını tarihsel roman kategorisinde görmemektedir. Ona göre çağ romanları ele aldığı konular, tipler

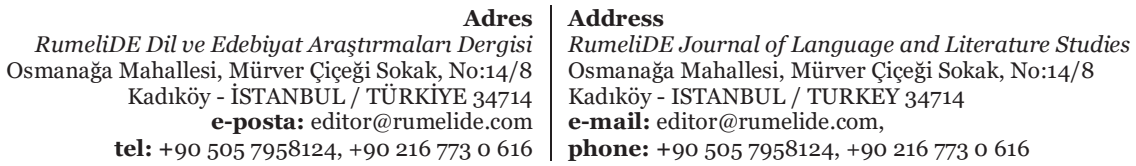


790 / RumeliDE Journal of Language and Literature Studies 2022.26 (February)

General evaluation on the concept of period novel / H. Genç (pp. 782-794)

ve karakterler açısından yazıldıkları dönemde güncel olmasına rağmen bugün tarihsel olan yapıtlarıdır. Günümüzde geçmişe ait olduğu için tarihsel olma özelliğine sahiptir (Şimşek, 2006).

Üslup açısından ele alırsak özellikle romantik üslubunun mirasıyla oluşan tarihsel romanlarda macera ağırlıktadır. İnsanlığı ve toplumları etkileyen savaşlar, kahramanlıklar, esrarengiz hikâyeler, polisiye bir kurgu, büyük maceralar ve dikkat çekici aşk hikâyeleri okuyucunun merakını kamçılayacak bir biçimde ayrıntılı ve sürükleyici bir şekilde aktarılmaktadır. Bu sayede okuyucu, etkileyici sahnelerin içinde kendisini bularak milliyetçi yanı ağır basmaktadır. Çağ romanı ise daha ziyade durağan bir üsluba sahiptir. Çağın genel görünümünü yansıtması ve yazarın çağını/yaşananları bu yapıtlarda sorgulaması nedeniyle kişilerin ve toplumun psikolojisi ön plandadır. Tarihsel romanlarda insanlığı etkileyen olaylar gerçekleşirken, çağ romanında önceden yaşanmış olayların izleri okuyucuya iletilmektedir.

Tarihsel romanın yanı sıra çağ romanın toplum tasviri bağlamında ortak paydada buluşan bir diğer tür ise toplum romanıdır (Gesellschaftsroman). Toplum romanı belirli bir çağda kapsamlı bir toplum tasviri yapması nedeniyle aslında çă̆ romanın bir biçimidir. Bu roman türü ile çok yakın ilişkide bulunan çă̆ romanının arasına kesin bir çizgi çekmek oldukça güçtür. Çünkü her ikisinde de toplumun iyi ya da kötü yönleri ortaya serilmekte ve bu şekilde çağ eleştirisi yapılmaktadır. Toplum romanında, çă̆ romanında olduğu gibi figürler arasında eşit değerlere sahip rol dağılımı ve birbirine paralel cereyan eden olay ve olay örgüleri bulunmaktadır. Ancak bu iki roman türü arasında önemli bir detay dikkati çekmektedir. Toplum romanı ile karşılaştırıldığında çağ romanı, toplumsal yaşamdan yola çıkarak yazarın hala içinde bulunduğu fikir hareketleri ve eğilimlerini gerçekçi bir şekilde ele alması şeklinde tanımlanabilmektedir (Göttsche, 2007: 883). Toplum romanı, genellikle belirli sosyal sinıfları ayrıntılı olarak tasvir etmeye odaklanırken, çağ romanı olabildiğince kapsamlı ve gerçekçi bir şekilde anlattığı döneme odaklanır. Çă̆ romanı özellikle 19.yüzyılın bir ürünü olarak görülmekte ve çoğunlukla Alman yazarlarca sınırlandırılmakta iken, toplum romanı kavramının altında ne zamansal ne de mekânsal açıdan bir sinırlama yer almamaktadır. Bu roman türü Hartmann von Aue'nin "Erec" ve "Iwein" yapitlarına kadar dayandırılmaktadır, kapsamlı bir şekilde 17.yüzyll için Philipp von Zesen, Grimmelshausen, Weise'nin örnekleriyle beraber alınmıştır. Goethe'nin Wilhelm Meister'ın “Theatralische Sendung” (1785) yapıtından sonra, Stendhal, Balzac, Zola, Tolstoy, Dostoyevski gibi 19. yüzyllın Avrupa kökenli roman yazarı listeleriyle tamamlanarak Almanca konuşulan bölgelerdeki çă̆ romanı yazarları toplum romanı yazarlarından sayılmaktadır (Jeske, 1981: 448).

Güncel konuları içeren bir diğer roman türü Almanca karşılığı "Gegenwartsroman” olan günümüze ait olan olay ve olguları işleyen romandır. Eleştirel çă̆ yansımalarının bulunduğu çağ romanlarında modern tarih olarak kolektif tarih deneyiminin tasvirinden hareket edebilmekte (Bu durumda politiktarihsel çağ romanı adını almaktadır.) ve doğrudan doğruya günümüze ait politik tartışmalara dâhil olabilmektedir. (Bu durumda ise sadece politik çă̆ romanı adını almaktadır.) Ayrıca bu eleştirel çağın yansıması olarak sosyal ya da kültürel yapılarını ve gelişmelerini kastettiğinde ise "Epochenroman" olarak adını almaktadır (Göttsche, 2007: 882). Dolayısıyla bu tarz romanları, çağ romanından kesin bir şekilde ayırmak güçleşmektedir.

Yazarların üslubuna ve görüşlerine yönelik bugünün anlaşıldığı çağ romanı, dayalı olduğu toplum ve kültür gerçeğini anlatım çabasıdır. Bu nedenle çă̆ romanı için zamanı belirleyen faktörler olan toplumsal, zihinsel-kültürel, geleneksel-dinsel, politik-askeri ve ekonomik alan olmak üzere beş adet konu alanı belirlenmiştir (Jeske, 1981: 447). Bu faktörler aynı zamanda çă̆ romanını gelişim ve eğitim romanından ayıran unsurlardır. Çünkü çağ romanında bir bireyin ya da bir grubun kaderini söz konusu değildir, aksine burada çă̆ gerçeğinin bireyler üstü ve kolektif yapısının tasviri yer almaktadır. Bu

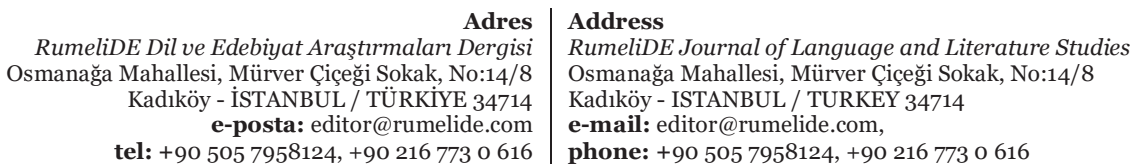


nedenle öncelikle gönül meseleleri olmak üzere baş karakterlerin kişisel kaderleri, onları bir çağı temsil etme konusunda yetersiz kılan bir özelliğe sahiptir. Oysa Worthmann roman bağlamında zaman boyutunun, insanların bir eylem olarak gerçekleşen somut kaderinde olmayıp aksine kişilerin ifadelerinde belirdiğini iddia etmektedir (Roger, 1975: 37).

Çağ romanında bulunan olay örgüsü yapıt boyunca ikincil bir öneme sahiptir. Olaylar devam ederken hikâyenin zamansal ilerlemesini muhafaza etmek için uğraşılmaktadır. Fakirlik ve zenginlik gibi tezatlık gösteren bir ilişkide birbirine doğru ilerleyen çağın genel görünümü ve anlık görüngülerin yan yana sıralanması şeklindeki olay örgüsü arasında vuku bulan şey tek başına asıl önemi taşımaktadır. Ancak olay örgülerin yan yana sıralanması gelişim romanındaki (Entwicklungsroman) gibi entelektüel ve ahlaki olgunluk değişimi kastedilmemektedir. Çünkü burada söz konusu olan birey değil, tamamen bir toplum ve çağdır (Jeske, 1981: 443).

Yazar, eğitim ve oluşum romanın miras bıraktığı formuna sıkı sıkıya bağlı kaldığı müddetçe, ifade amacı ideal bir tip olmaktan çıkmaktadır. Çünkü gerçekliği yansıtmak isteyen yazar, toplumsal gerçekliğin aslında nasıl farklı ve çelişkili olduğunun ve bireylerin de yaşamları için yaptıkları belirsiz planlarının farkına varmaktadır. Böylelikle yazar kahramanını dünya karmaşasının tam ortasına yerleştirmekte, böylece bu kişi de çağın anlayışı, sosyal çevre direnci ve birlikte yaşadığı insanların tuhaflıklarıyla çektiği sıkıntıyı ve kendisini kusursuz ve genel geçer bir şahsiyete yükseltmeden kişiliğini geliştirdiğini göstermektedir. Bu nedenle oluşum romanı (Bildungsroman) yerine tarafsız olan gelişim romanı (Entwicklungsroman) kavramını kullanmak daha doğru olmaktadır (Rinsum, 2006: 48). Ancak çă̆ romanının oluşum romanından ayıran önemli bir özellik bulunmaktadır. Oluşum romanı gibi bireysel romanın aksine çă̆ romanı politik ve sosyal açıdan çağın belgelere dayanan ya da kurmaca görünümlerinin kendi koşulları ve ana hatlarının dâhilinde gözler önüne serilmesi ve eleştirilmesi sonucu edebi birer çaba olarak ortaya çıkmıştır (Göttsche, 2007: 881). Ancak oluşum romanın aksine, çağ romanı (belgesel veya kurgusal) bir görüntüsüne yönelik edebi bir girişim olarak siyasi ve / veya sosyal çağdaş tarihin temsili ve eleştirisi yoluyla oluşur.

Eğitim ve oluşum romanın yanı sıra çağ romanı profesör romanı (Professorenroman) ile ortak bir noktaya sahiptir. Çağ romanında önemli bir ilke olan gerçeklik bağlamında çağın şartlarına uygun olarak gerçeğe yakın bir şekilde her hangi bir okuyucunun olduğu kadar aydın kesiminin de ilgisinin çekecek olan yazar, çok sayıda aydının uzmanlık alanına kolaylıkla ulaşılabilir kılma amacını taşımaktadır. Bilgililik ve bilgi verme gayesi yapıtlara "Profesör romanı" adını kazandırmaktadır. Ulus devleti çabalarının esnasında "Profesör romanı" yazarları Alman geçmişine yönelmişlerdir (Rinsum, 2006: 50).

Çă̆ romanında kurmaca unsurların ağır basmasının yanı sıra tarihsel romandaki gibi gerçeğe bağlı kalma çabası belirli bir yer ve zaman isimlendirmeleriyle kendini belli etmektedir. Toplumu eleştirip ideal olana yönelmesi çağ romanını ütopi romanı ile arasında bir benzerlik oluşturmasına rağmen çă̆ romanında gerçekliğe bağlı kalma düşüncesi daha ağır gelmektedir. Bu nedenle çağ romanında hayali unsurlar hiç bir şekilde söz konusu değildir. Bu durumda çağ romanı dünyanın toplum tarafından belirlenen durumunu daha doğrusu insanlık tarihini ifade etmeye çalışması sayesinde ütopi romanından farklılık göstermektedir (Jeske, 1981: 444). Çă̆ romanının reddettiği ütopik unsurun var olması daha doğrusu eksikliği türün genel olarak sınıflandırılmasına yardımcı olmaktadır. Öte yandan ütopide geleceğe yol gösteren varyant, geçmişe yöneltilen varyanttan ayrılmaktadır. Bu tarz ütopilerde varsayılan çağ eleştirisi - bu açıdan bakıldığında Ütopik roman arasındaki fark da ortaya çımaktadır. Çağ eleştirisi, bu ütopilerde belirli ve istenilen çözümler sunması halinde gerçeklik ilişkisi aramaktadır. Bu çağ eleştirisi kimi zaman Immermann'ın “Münchhausen” örneğinde olduğu gibi yergi ile kimi zaman

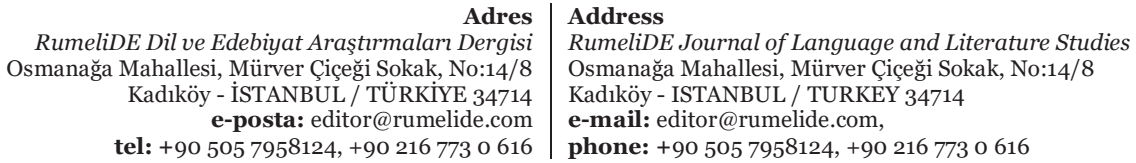


da Spielhagen'in “In Reih und Glied” ya da Gutzkow'un "Die Ritter vom Geiste” örneklerinde olduğu gibi protesto aracılı̆̆ıla dile getirilmektedir (Jeske, 1981: 448).

Gerçeklik, çağ romanında kişiler üzerinde farklı bir işleve de sahiptir. Anahtar roman (Schlüsselroman), Mektup roman (Briefroman), tarihsel roman ve çağ romanı gibi gerçekliğe dayalı roman figürlerinde bu figürlerin yapısal oluşumunu gerçeklik belirlemektedir. Aytaç'ın tanımıyla anahtar roman "kastedilen kişilerin, olaym veya yerin okuyucu tarafindan ancak bilmece çözer gibi kafa yorarak anlaşılabileceği, üstü kapalı bir şekilde anlatıldığı roman" (Aytaç, 2009: 198) anlamına gelmektedir. Oysa anahtar romanda gerçek kişilerin olay, durum veya kaderleri veya mekânlar sadece uydurma isimleriyle örtülü bir biçimde sunulmaktadır. Böylelikle söz konusu bu durum veya olaylar sadece özünde onu bilenler için tanıdık gelebilir ya da gerçekliğe yapılan anahtar görevindeki bir işaret aracılı̆̆ıyla deşifre edilebilir (Müller, 1998). Çă̆ romanı belirli kişilerin daha kısa olan olaylarına içerik açısından kısıtlama getirdiği ve ayrıca çă̆ın figürlerinin edebileştirilmesiyle yetinmeyip aksine gerçeğin tasvirindeki bütünlüğü hedef aldığı için Anahtar romanın gerekliliklerini yerine getirememektedir (Jeske, 1981: 446). Gerçek olay ve kişilerin örtülü bir biçimde anlatıldığı Anahtar romanda olduğu gibi mektup yazarı romanının yarattığı tipler gerçek şahsiyetlerin hayatlarının ela alınması açısından çă̆ romanı kişileri ile bağlantısı bulunmaktadır. Mektup romanı gerçekliğin yansıtıldığı ben anlatımın bir biçimidir.

19. yüzyılın çă̆ romanının paralelinde kendi şeklini bulan "Dorf- ve Heimatromanı", özellikle Jeremias Gotthelf in "Bauernspiegel" (1837) ve "Uli der Knecht" (1841/46) adlı yapıtları, yerel ve kişisel sınırlamalarla çă̆ romanına yöneltilen gereklilikleri kısmen karşılamaktadır. Sonuç itibariyle sosyalist realizm romanları tarihi açıdan 19. yüzyıldaki çă̆ ve toplum romanın geleneğinin bir devamı olarak görülmektedir (Jeske, 1981: 447).

Çağ romanı ile yakından bağlantılı olan bir diğer tür ise aile kroniği ya da aile romanıdır. Göğebakan, aile kroniğin çă̆ roman ile aynı işleve sahip olduğunu dile getirerek arasındaki ilişkiyi şu şekilde vurgulamıştır:

"Yazar çağın panoramasını, sosyal değișme ve gelişmeleri bir ailenin birkaç kuşağı aracthğıyla şekillendirir. Okur ailenin öyküsünü izlerken çağın öyküsüyle de tanışır.” (Göğebakan, 2007:503)

Bu türe örnek olarak Thomas Mann'nn “Buddenbrook Ailesi” ve Orhan Pamuk'un “Cevdet Bey ve Oğulları" adlı yapıtları gösterilmektedir. Aust aile kroniğine bürünen tarihi konu edinen roman türü şu sözleri dile getirmektedir:

"Nesil romanı ya da aile kroniği olarak ashnda örtük geçmişi, güncel olan şimdiki zamana taşımaktadır. Benzer durum otobiyografi ya da anı edebiyatı için de geçerlidir.” (Aust, 1994: 32)

Çağ romanına benzer bir şekilde merkezinde yazarın yaşadığı ve modern çağ ile bağlantısı olan bir geçmişin tasvirinin gerçekleştiği aile romanında tanıklar ve / veya çağdaş eğilimlerin temsilcileri ve eleştirmenleri olarak kahraman veya küçük çevre yer almaktadır. Aust çağ romanı gibi yakın tarihteki olayları anlatan roman tiplerinin arasına savaş romanı ve geçmişle hesaplaşma romanı da ilave etmiştir. "Bugünkü zamanlar tarihi romanında3 (özellikle her iki dünya savaşı arasında savaş romanı ile kıyaslanarak) ve geçmişle hesaplaşma romaninda (1950'li ve 1960'l yıllarda) geçmiş mesafe ve

Bknz. Almanca Karşılı̆ğ “Zeitgeschichtsroman”dır.

Adres

RumeliDE Dil ve Edebiyat Araştırmaları Dergisi Osmanağa Mahallesi, Mürver Çiçeği Sokak, No:14/8 Kadıköy - İSTANBUL / TÜRKIYE 34714 tel: $+905057958124+902167730616$
Address

RumeliDE Journal of Language and Literature Studies

Osmanağa Mahallesi, Mürver Çiçeği Sokak, No:14/8

Kadıköy - ISTANBUL / TURKEY 34714

e-mail: editor@rumelide.com

phone: +90 5057958124, +902167730616 
bütünlük ölçüt alındığında tarihsel bir roman için bir konu veremeyecek kadar yakn" (Aust, 1994: 32) olması, tarihi konu edinen bir roman için gerekli olan zaman ölçütü vurgulanmıştır.

Çağ romanı ise geçmiş ve geniş bir zaman dilimine ait olan bir dizi olayların peş peşe aktarılmasıdır. Çă̆ romanında yer alan bu olaylar dizisi "birkaç romanlk bir seri olarak da çıabilir okurun karşısına. Nehir/ırmak romanları da bu nedenle çă̆ romanları olarak kabul edilebilir” (Göğebakan, 2007: 503). Nehir roman (Roman-Fleuve) olarak da adlandırılan çağ romanı toplumun geniş bir görünümünü seriler halinde anlatan çok uzun bir roman türüdür. Çă̆ romanı ile bağlantısı olan bir başka roman türü eve dönüş romanıdır. Almanca karşılığı "Heimkehrerroman" olan bu roman türünün merkezinde "savaştan ya da hapisten dönen, maddi ylkım ve toplumsal ve ahlaki düzenlerin ortadan kaldırılmasıyla belirlenen bir ortamda kendini yeniden yönlendirmeye çalışan bir kişi” (Burdorf vd. 2007: 307) yer almaktadır. Bu kişi başından geçen bir dönemi, atlattı̆̆ı belli bir çağın anılarıyla evine geri dönmektedir. Özellikle İkinci Dünya Savaşı'ndan sonra ilginin arttı̆̆ı Eve Dönüş romanı bireysel kaderin ötesine geçen zamanın analizi yapılmakta ve kökten değişmiş bir gerçeklikte geriye kalanları belirlemeye çalışan bir envanter oluşturmaktadır. Yazarlar günümüzde yürütülen savaşların söylemini üstlenerek evden ayrılma ve eve dönüş süreçlerini içinde barındıran belli bir çağın görünümünü çizmektedir.

\section{Sonuç}

Çağ romanları güncel olan toplumsal sorunları irdeleyen, eleştiren ve bunları okuyuculara sunan bir roman türüdür. Özellikle insanlık için dönüm noktası niteliğindeki tarihsel olayları konu edinen diğer romanlarda olduğu gibi bu romanlarda da gerçek olayların aydın kimliği ile yazarın akıl ve ruh süzgecinden geçirerek kurgusal boyutta yeniden şekillendirilmesi söz konusudur. Gerçek gerçekliğin kurmacalaştırılarak ifade edildiği çağ romanlarında önemli olan içerik olup, söz konusu edilen çağın eleştirisinin ön planda olması gerekmektedir. Bu bağlamda yazarlara göre çă̆ romanları politik fikirlerini dile getirmek için kullanılan araç anlamına gelmektedir.

Çağın arka planda yer aldığı roman türlerinin birbirleriyle karşılaştırıldığında - örneğin tarihsel romanlarda merkezi bir ana karakter yerine, çağ romanında çok sayıda eşdeğer temsilci bulunması örneğinde olduğu gibi - figürlerin özellikleri, kurmacanın kullanımı ve ana olayın işlenmesi gibi biçimsel değişiklikler yer almaktadır. Bu durumda özellikle tarihsel roman ve çağ romanların karşı karşıya kaldığı durumlarda iki roman arasındaki farkı ayırt etmek için yazarın sözünü ettiği olaya zamansal yakınlığına bakılmaktadır. Bu tarz farklılıklar olmasına rağmen temelde tarih ve edebiyatın bir arada bulunması, edebiyatın tarihten beslenmesi, toplumsal ve politik konuları kullanması bakımından ortak paydada buluşmaktadırlar. Çağı konu edinen romanların bir başka ortak özelliği sanat kaygısının yer almamasıdır. Dolayısıyla çağın konu ve zaman olarak yer aldığı romanlarda da benzer şekilde gerçeklik ve kurmaca ilişkisine dayanarak bir takım benzerlikler ve farklılıklar bulunmaktadır. Ancak çă̆ romanını belirleme konusunda araştırmacılar, yazarın yapıtında aktardığı zamana uzaklığı/ yakınlığı belirleme tekniği hemfikirdir.

Genel olarak bakıldığında çağı konu edinmek isteyen yazarların amaçları; bir aydın olarak toplumun aksak yönlerine ve rahatsız edici durumlarına karşı tepkilerini göstermek, suskunların sesi olmak ve okuyucularda farkındalık yaratmaktadır. Bu şekilde yazarın okuyuculara ilettikleri bilgilendirme birer belge niteliği taşımakta, daha sonraki nesillerde de benzer tepkiler oluşmasını sağlamaktadır. Sonuç olarak çă̆ romanlarını çağın sorunlarını irdeleyen veya daha uzak geçmişe ait olayları gündeme taşıyan roman türlerinden ayrı bir tür olarak değerlendirmek gerekmektedir.

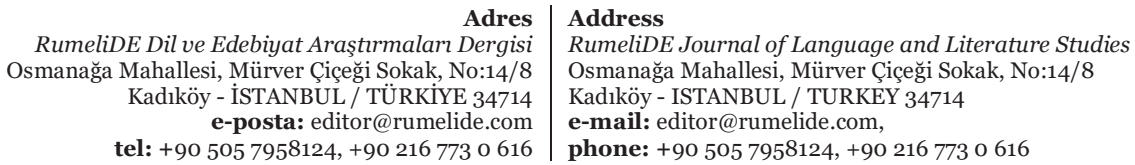




\section{Kaynakça}

Antakyalığlu, Z. (2013). Roman Kuramına Giriş. İstanbul: Ayrıntı Yayınları.

Argunşah, H. (2002). Tarihî Romanın Yükselişi. Hece (Türk Romanı Özel Sayısı), S. 65-67. s.454-464.

Argunşah, H. (2006). Tarihi Roman, Türk Edebiyat Tarihi4. İstanbul: Kültür ve Turizm Bakanllğı Yayınları.

Argunşah, H. (2016). Tarih ve Roman. İstanbul: Kesit Yayınları.

Aristoteles. (1987). Poetika. İstanbul: Remzi Kitabevi.

Aust, H. (1994). Der Historische Roman. Stuttgart: Verlag J.B. Metzler.

Aytaç, G. (1999). Çağdaş Türk Romanı Üzerine İncelemeler. Ankara: Gündoğan Yayınları.

Aytaç, G. (2003). Genel Edebiyat Bilimi. İstanbul: Say Yayınları.

Aytaç, G. (2009). Karşılaştırmalı Edebiyat Bilimi. İstanbul: Say Yayınları.

Burdorf, D., Fasbender, C., Moennighoff, B. (2017). Metzler Lexikon Literatur: Begriffe und Definitionen. Stuttgart: Springer-Verlag.

Eco, U. (2011). Genç Bir Romancının İtirafları. İstanbul: Kırmızı Kedi Yayınevi.

Glaser, H.A. (1983). Deutsche Literatur Eine Sozialgeschichte Band 9. Weimar Republik-Drittes ReichAvantgardismus-Parteilichkeit- Exil 1918-1945. Hamburg: Rowohlt Verlag.

Göğebakan, T. (2004). Tarihsel Roman Üzerine. Ankara: Akçă̆ Yayınları.

Göğebakan, T. (2007). “Tarihsel Romanda Ölçüt/Sınıflandırma Sorunu”, Erciyes Üniversitesi II. Kayseri ve Yöresi Kültür, Sanat ve Edebiyat Bilgi Şöleni, 10-12 Nisan 2006.

Göttsche, D. (2007). Zeitroman. Klaus Weimar (Der.), Reallexikon der deutschen Literaturwissenschaft Band III. Berlin-New York: de Gruyter.

Hartmann, H. Zeitkritik im Zeitroman, s.739. http://library.fes.de/gmh/main/pdffiles/gmh/1961/1961-12-a-739.pdf [Erişim Tarihi: 15.08.2012]

Hillebrand, B. (1978). Zur Struktur des Romans. Darmstadt: Wissenschaftliche Buchgesellschaft.

Hillman, R. (1975) The Zeitroman From 1830-1900. Adelaide. https://digital.library.adelaide.edu.au/dspace/handle/2440/20861 [Erişim Tarihi: 11.10.2021]

Jeske, W. (1981). "Der Zeit-und Gesellschaftsroman” (Ed. Otto Knörrich), Formen der Literatur in Einzeldarstellungen. Stuttgart: Alfred Kröner Verlag.

Meid, V. (1999). Sachwörterbuch der deutschen Literatur. Stuttgart: Reclam.

Müller, S. (1998). Studienbuch Neuere Deutsche Literaturwissenschaft, Königshausen Neumann.

Rinsum, A. (2006). Deutsche Literaturgeschichte Band 7 Realismus und Naturalismus, München: Deutscher Taschenbuch Verlag.

Schneider, J. (2016). Einführung in die Roman-Analyse. Darmstadt: WBG (Wissenschaftliche Buchgesellschaft.

Stöckmann, I. (2011). Naturalismus Lehrbuch Germanistik. Stuttgart: J.B. Metzler.

Şimşek, A. (2006). Tarihsel Romanın Eğitimsel İşlev, Ahmet Yesevi Üniversitesi Mütevelli Heyet Başkanlığı, Bilig, sayı 37, ss.65-80, http://www.yesevi.edu.tr/files/article/20.pdf [Erişim Tarihi: 14.09.2012]

Tepebaşılı, F. (2005). Edebiyat Yazıları. Ankara: Hece Yayınları.

Tural, S. (2003). Zamanın Elinden Tutmak. Ankara: Yeni Avrasya Yayınları.

Wolfgang, van R. (2006). Deutsche Literaturgeschichte Band 7 Realismus und Naturalismus. München: Deutscher Taschenbuch Verlag.

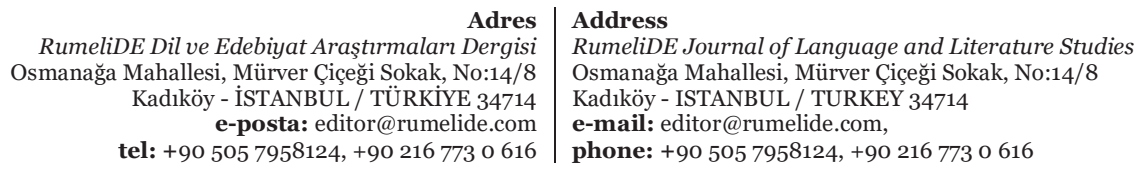

